\title{
A pilot study of corporate governance and accounting fraud: The fraud diamond model
}

\author{
Imang Dapit Pamungkas \\ Universitas Pekalongan, Indonesia \\ Imam Ghozali \\ Tarmizi Achmad
}

Faculty of Economic and Business, Universitas Diponegoro, Indonesia

\author{
Keywords \\ Corporate Governance, Accounting Fraud, Fraud Diamond
}

\begin{abstract}
This research aimed to analyze the risk factor of fraud diamond model towards accounting fraud and corporate governance as a moderating variable in relation with risk factor in fraud diamond model towards accounting fraud. This research using 12 fraud companies and 32 non-fraud companies listed by Indonesia stock exchange that breaking the article VIII.G.7issued by Financial Services Authority. With using logistic regression, the research result shows that only change in direction that is affect significantly towards accounting fraud. The next result, it shows that board of commissioners, independent commissioners and institution ownershipbe able to weaken the relation of change in direction towards accounting fraud. This research can suggest to the investors to be more careful in investing their fund. Especially, in the company that carries out the higher change in direction, because it tends to have accounting frauds. Furthermore, the company can improve the board of commissioners, independent commissioners and iinstitution ownershipp, so that the level of accounting fraud can be lowered.
\end{abstract}

Corresponding author: Imang Dapit Pamungkas

Email addresses for corresponding author: imangunikal@gmail.com

First submission received: 4 th June 2017

Revised submission received: 30th August 2017

Accepted: 28th September 2017

\section{Introduction}

Fraud diamond is a new viewpoint towards fraud phenomenon stated by (Wolfe and Hermanson, 2004). Wolfe and Hermanson (2004) Stated that there is a renewal of fraud triangle theory to improve the ability to detecting and preventing fraud by adding the fourth element: capability. Opportunity opens opportunities or opens the doors of fraud, while pressure and rationalization encourage people in doing fraud. According to Wolfe and Hermanson (2004), people whom carrying out the fraud must have the capability to realize the open doors as a good opportunity and to use it, not only once but for many times. This theory explains that the key on mitigating the fraud is to focus on certain situation occurred beside pressure and rationalization and also combination from opportunity and capability.

Financial reports are very vulnerable to fraud. Considering the importance of the financial statements that are free from of fraud, so that the preparation of financial statements must be in accordance with the actual circumstances and in accordance with the SAK. But in fact, there are many irrelevancies such as manipulation of the amount, disclosure, mark-up, and eliminating data in the presentation of financial statements. The irregularities in presenting the financial statements are the examples of accounting fraud.

Accounting fraud is not just occured in developed countries like the Enron Case that is occured in 2002 in the United States, where the company management engineered the financial statements so that profits occur up to USD 600.000.000, where the company actually suffered losses (Tuanakotta, 2007). Other case also happened in WorldCom. The Executive of the company engineered the financial statements by including USD 3.900 .000 post investment which should be included as operating cost (Tuanakotta, 2007). However, accounting fraud has also occurred in companies in Indonesia. An example 
of a case of accounting fraud that undermines the trust chains of users of financial statements with management is the unfolding case of PT. Kimia Farma which marks up their financial statements.

According to the previous research, it shows that there was an inconsistency of the research result related to the perspective of diamond fraud. First, Financial Target, done by (Ansar, 2012; Fimanaya and Syafruddin, 2014; Lou and Wang, 2009; Rahmanti and Daljono, 2013) where their research results showed the significant effect towards accounting fraud. Second, ineffective monitoring, done by (Antonia, 2008; Skousen, Smith and Wright, 2009) their research results showed the significant effect towards accounting fraud. However, the research results of (Rahmanti and Daljono, 2013; Ratmono, Avrie, and Purwanto, 2014; Skousen et al., 2009) showed that ineffective monitoring has no effect on accounting fraud. Furthermore, related to the rationalization, the research done by (Chen and Elder, 2007; Sukirman and Sari, 2013) showed that it has significant effect to accounting fraud. However, it was different with the research done by (Fimanaya and Syafruddin, 2014; Ratmono et al., 2014) where rationalization has no effect on accounting fraud.

Wolfe and Hermanson (2004) clearly explain that Change in Direction can cause stress period where lead to the fraud. Dechow, Sloan, and Sweeney (1996) in relation to the acts of fraudulent financial reporting has researched the issues of corporate governance structure and the level of concentration of ownership by the insider. His research showed that when the concentration of ownership is owned by the company, the fraud will be easily occurred. The fraudulent financial reporting is also associated with the issues of corporate governance structure. Dechow et al., (1996) clearly stated that the level of fraudulence mostly occurred in a company that has no good corporate governance structure. This research intended to examine and analyze the role of corporate governance mechanism in preventing accounting fraud in the perspective of diamond fraud by (Wolfe and Hermanson, 2004). This Study is only a pilot study because there are insufficient observations for a definitive study: the sample of 44 observations contains 12 fraud cases and 32 non-fraud observations. According to the phenomenon's and research gap, where there were inconsistencies in the results of the study, so it is motivating and interesting to do further research. This study considers the mechanism of corporate governance as a moderating variable to bridge the research gap. This research's question is whether corporate governance mechanism can prevent accounting fraud in the perspective of fraud diamond. The purpose of this research is as follows: (1) examine the influence of financial target against accounting fraud, (2) examine the influence of ineffective monitoring against accounting fraud, (3) examine the influence of change in auditor against accounting fraud, (4) examine the influence of change in direction against accounting fraud, (5) examine the influence of corporate governance mechanisms in relation with financial target, ineffective monitoring, change in auditor and change in direction against accounting fraud.

\section{Literature Review and Hypotheses Development}

Jensen and Meckling (1976) explain that the occurrence of agency problems is the result of a contract between the principal and the agent. In practice, corporate managers act as agents with the responsibility increasing the profits of the owners, but the managers also have an opportunity to maintain their welfare (Ujiyantho and Pramuka, 2007). The difference of interest between principal and agent resulted in a conflict of interest. With the existence of conflict of interest is causing various pressures for the company, where the company must improve its performance in order to provide rationalization. The possibility of fraud could easily occur when the management have the ability, access and strong and strategic position (capability) and also opportunities to do accounting fraud (opportunity).

The company uses agency theory in tracing the corporate governance mechanism. The rise of the accounting fraud cases has seized the attention of many academics and economists to develop various theories which are able to detect fraudulent activities. One of the theories is the fraud diamond risk factor theory. Therefore, this research put corporate governance mechanism as a moderating variable to complete the research gap on the relation of risk factors to accounting fraud. The relationship model between researches variables is shown in Figure 1 as follows: 


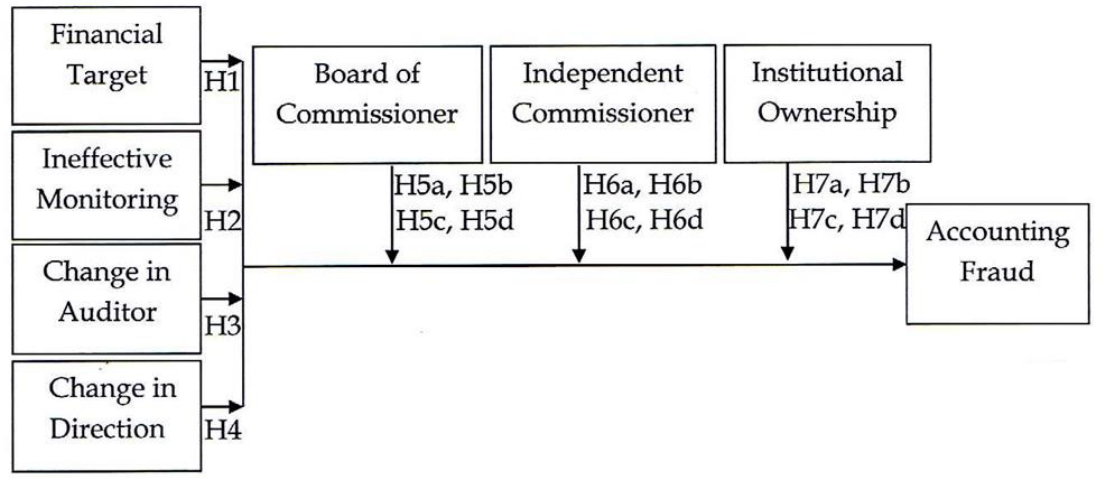

Figure 1. Research Model

\subsection{The Influence of Financial Target on Accounting Fraud}

Managers are required to work optimally in achieving company's targets. Managers try to improve its performance in order to achieve the targets of the company, one of them is financial target.Skousen et al., (2009) said that Return on Assets (ROA) is a ratio which measures operational performances where reflects the level of efficiency of assets used. It is supported by (Kasmir, 2013) who said that ROA is a result or return on the resources used. Therefore, ROA is used as a proxy for financial targets. Furthermore, ROA can be used by the company on measuring its performance on making a profit. The higher the ROA, the higher the profit obtained by the company and also the better the condition of the company if it seen from the use of its assets.

The achievement of ROA in current year can be used as a determination of financial targets in the following year. The higher the ROA, the better the performance of the management, which means the whole company's operations have been considered as effective. However, in improving its performance by targeting the higher ROA may allow management to commit accounting fraud. This is similar to the result of (Widyastuti, 2009) that when the company has a high profit, the level of fraudulence will get higher. Thus, the hypothesis in this study stated as follows:

H1: Financial Targets has Positive Influence on Accounting Fraud

\subsection{The Influence of ineffective Mmonitoring on Accounting Fraud}

The accounting fraud is one of the impact of weak monitoring level or even lack of adequate supervision system. Such conditions will lead to fraud because the opportunities to do things that may harm and break the company rules is very widely open (Andayani, 2010) Companies that have a low level of supervision has a lot of potential for all forms of crime including accounting fraud. The enforcement of standard operating procedures and implement a good supervision system becomes an obligation for the company to avoid fraudulences. So that the hypothesis of the research stated as follows:

H2: Ineffective Monitoring has Positive Influence on Accounting Fraud

\subsection{The Influence of change in Aauditor on Accounting Fraud}

Rationalization is one of the risk factors of the fraud triangle that leads to fraud. The substitution of auditor or public accounting firm become the proxy of rationalization (Skousen et al., 2009). According to (Loebbecke, Eining, and Willingham, 1989; Stice, 1991) found that the fraud occurs during the auditor's tenure which is still in its first two years of service. This is similar to (Albrecht and Albrecht, 2002) who stated that auditor turnover is related to accounting fraud. The auditor turnover results in a stress period and the transition period of a company. One of the indications of accounting fraud is the change of auditor in two years period. The higher the auditor turnover, the higher the accounting fraud rate. So that the hypothesis of the research stated as follows:

H3: Change in Aauditor has Positive Influence on Accounting Fraud

\subsection{The Influence of change in Direction on Accounting Fraud}

Wolfe and Hermanson (2004) argue that a fraud will not occur if it is not done by someone with the right ability and the right position to carry out every single detail of the fraud. Capability means one's efforts in committing fraud in order to achieve certain goals. Wolfe and Hermanson (2004) also explained 
that position, effective lying, immunity to stress, brains, ego, and coercion skill are the elements capability. The position of CEO's, directors, and heads of other divisions are likely to be most appropriate to those characteristics. That position can become a determinant in act of fraud by using their position to influence others to expedite their acts of fraud.

Sihombing and Rahardjo (2014) use Change in Direction as a proxy of capability to identify the indications of accounting fraud. Change in Direction makes initial performance of the company not optimal. This is due to the company in transition period so that it takes a while to do some adjustment (Sihombing and Rahardjo, 2014) Change in Direction leads to conflict of interest because in general it is politically motivated and there are interests of certain parties.

Wolfe and Hermanson (2004) clearly stated that capability that proxied with Change in Direction becomes the background and triggered an act of fraud. Change in Direction can be considered as a strategy in eliminating traces of previous directors which is considered knowing the variety of fraud that has been done by the company. Change in Direction also cause a transition period and stress period that triggered the opportunities and the chance to do an act of fraud (Brennan and Kelly, 2007). So that the hypothesis of the research stated as follows:

H4: Change in Direction has Positive Influence on Accounting Fraud

\subsection{The Role of the Board of Commissioners on the relationship of Financial Target, Ineffective Monitoring, Change Auditor and Change in Direction towards Accounting Fraud.}

The board of commissioners has full authority and responsibility in controlling, supervising and directing the management of company resources (Syakhroza, 2005). When a company has a Board of Commissioners that works effectively then the performance of the company will also be good. The quality of this function is a determinant of corporate governance effectiveness. The differences of interests between the owners of the company and management can be aligned with corporate governance mechanism. The quality of corporate governance mechanisms is extensively related to the quality of the company (Tangjitprom, 2013). The monitoring done by the board of commissioners and shareholders is an important mechanism in aligning shareholder and management interests. The effectiveness of company monitoring conducted by an independent board of commissioners will minimize the fraud. Despite of the high rates of financial targets, ineffective monitoring, change in auditors and change in direction. The Board of Commissioners has the responsibility of supervising the management and ensuring the implementation of corporate management, enforcement of SOPs and obligations of corporate accountability in accordance with the results of the corporate governance forum in 2003.

The same thing was also delivered by (Dechow et al., 1996; Dunn, 2004) where the composition of the board of commissioners capable on preventing any act of fraud. Based on (Governance, 2004), the board of commissioners has responsibility and authority in the management monitoring process. The board of commissioners is a corporate governance mechanism that predicted can affect managerial opportunistic behaviour so that the hypotheses of the research stated as follows:

H5a: The Board of Commissioners has moderation on the relationship of Financial Target towards Accounting Fraud

H5b: The Board of Commissioners has moderation on the relationship of Ineffective Monitoring towards Accounting Fraud

H5c: The Board of Commissioners has moderation on the relationship of Change in Auditor towards Accounting Fraud

H5d: The Board of Commissioners has moderation on the relationship of Change in Director towards Accounting Fraud

2.6. The Role of the Independent Commissioners on the relationship of Financial Target, Ineffective Monitoring, Change Auditor and Change in Direction towards Accounting Fraud.

The effectiveness of the board of commissioners will strengthen the CEO, where CEO's strength is influenced by the level of independency of the board of commissioners. The Independent Commissioner is a member of the board of commissioners who is not affiliated with the controlling shareholder, between commissioners, the management, and other parties who capable of affecting their level of independency and only working for the welfare of the company. 
Independent commissioner is a strategic position in carrying out supervisory functions in the implementation of good corporate governance. The research result of (Marrakchi Chtourou, Bedard, and Courteau, 2001) concluded that when there is an independent board of commissioners, it can affect accounting fraud since in the process of supervision they work independently. When an independent commissioner increases their supervision, the accounting fraud rate will get lower. This is similarly stated by (Lim, Matolcsy, and Chow, 2007) that the board of commissioners which is dominated by the internal directors tend to have weak corporate governance. Thus, accounting fraud can be minimized by presenting independent commissioners because an independent commissioner is an independent party that represents a shareholder whose job is to specifically oversee the managerial actions. Accounting fraud will be reduced because they are supervised by an independent commissioner although the rate of financial targets, ineffective monitoring, change in auditors and change in direction are high. So that the hypotheses of the research stated as follows:

H6a: The Independent Commissioners has moderation on the relationship of Financial Target towards Accounting Fraud

H6b: The Independent Commissioners has moderation on the relationship of Ineffective Monitoring towards Accounting Fraud

H6c: The Independent Commissioners has moderation on the relationship of Change in Auditor towards Accounting Fraud

H6d: The Independent Commissioners has moderation on the relationship of Change in Director towards Accounting Fraud

2.7. The Role of the Institutional Ownershipon the relationship of Financial Target, Ineffective Monitoring, Change Auditor and Change in Direction towards Accounting Fraud.

Institutional ownership is a proxy for corporate governance mechanism that is predicted weakening the relationship of fraud diamond risk factors towards accounting fraud. Beiner, Drobetz, Schmid, and Zimmermann (2004) explain that the institutional ownership is seen based on the total percentage of voting rights which are owned by the institution. Institutional ownership has the ability to control management through effective monitoring so it will to minimizing the fraud. Cornett, Marcus, Saunders, and Tehranian (2007) stated that supervision done by institutional investors is also could encourage managers to prioritize the company performance that can minimize opportunistic management behaviour. The existence of institutional ownership will minimize the accounting fraud, so that the financial statements can describe the real concept even though the financial targets, ineffective monitoring, change in auditors and change in direction are high. So that the hypotheses of the research stated as follows:

H7a: The Institutional Ownership has moderation on the relationship of Financial Target towards Accounting Fraud

H7b: The Institutional Ownership has moderation on the relationship of Ineffective Monitoring towards Accounting Fraud

H7c: The Institutional Ownership has moderation on the relationship of Change in Auditor towards Accounting Fraud

H7d: The Institutional Ownership has moderation on the relationship of Change in Director towards Accounting Fraud

\section{Data and Methodology}

\subsection{Data Collection}

This study uses a quantitative approach because it leads to generalization, explains the various phenomenons and examines the theory with numeric variables, data analysis and multiple verification using statistical procedures. The population of this research that non-financial companies listed on the BEI. Furthermore, the selection of samples based on purposive sampling method.

\subsection{Operational Definition of Variables}

All the components of risk factors based on Fraud diamond cannot be observed directly. Furthermore, pressure is proxied with the financial target (ROA), opportunity is proxied by ineffective monitoring (BDOUT), rationalization is proxied by change in auditor ( $\triangle \mathrm{CCPA}$ ) and capability is proxied 
by Change in Direction (DCHANGE). Then, corporate governance mechanisms proxied with board of commissioners, independent commissioners and institutional ownership.

\subsection{Data Analysis Method}

This study examines hypotheses with binary logistic regression to analyze the effect of financial targets, ineffective monitoring, change in auditors, and change in direction moderated by corporate governance mechanisms against accounting fraud. According to (Ghozali, 2006) research with logistic regression ignores normality testing for independent variables. Due to this research using logistic regression where independent variables are combined non-metric and continue or metric categorical, so it also ignores the problem of heteroscedasticity. Regression model 1 is on the factors that affect accounting fraud. Furthermore, for model 2 with analysis technique based on interaction regression due to quasi moderating. Logistic regression model in hypothesis testing on model 1 is $\operatorname{Ln}(\mathrm{F} / 1-\mathrm{F})=\beta 0+\beta 1 \times 1+\beta 2 \times 2$ $+\beta 3 \times 3+\beta 4 \times 4+\mathrm{e}$ and hypothesis testing on model 2 is $\operatorname{Ln}(\mathrm{F} / 1-\mathrm{F})=\beta 0+\beta 1 \times 1+\beta 2 \times 2+\beta 3 \times 3+\beta 4 \times 4+$ $\beta 5 \times 5+$ e. Where, Ln $(\mathrm{F} / \mathrm{1}-\mathrm{F})=$ dummy variable, the company which commit accounting fraud represented with (1) and who did not commit accounting fraud represented with (0), X1= Financial Targets, $\mathrm{X} 2=$ Ineffective Monitoring, $\mathrm{X} 3=$ Change in Auditor, $\mathrm{X} 4=$ Change in Direction, $\mathrm{X} 5=$ Board of Commissioners, $X 6=$ Independent Commissioners, $X 7=$ Institutional Ownership, $\beta 1, \beta 2, \beta 3$, $\beta 4$, dan $\beta 5$ (regression coefficient) and e $=$ error

Based on SPSS output, testing was conducted with the various stages that must be passed as follows: first, assess the Hosmer and lemeshow goodness of fit test or feasibility on the regression model. Second, the coefficient of determination. Third, the Overall Model Fit. Furthermore, descriptive statistical analysis which includes the number of samples, mean, maximum and minimum and standard deviation.

\section{Discussion and Conclusion}

\subsection{Sample and Research Data}

The following explanation is the result of sample selection based on purposive sampling which brings about 12 fraud companies and non-fraud companies of 32 for the period of 2011-2015, as shown in Table 1 and Table 2 as follows:

Table 1

Sample Selection Procedure for Fraud Companies

\begin{tabular}{|l|l|}
\hline Sample criteria & $\begin{array}{l}\text { Companies that } \\
\text { meet the criteria }\end{array}$ \\
\hline $\begin{array}{l}\text { The population of non-financial companies where listing on } \\
\text { the BEI in 2011-2015 }\end{array}$ & 411 \\
\hline $\begin{array}{l}\text { Companies violating article } \\
\text { in 2011-2015 }\end{array}$ & 39 \\
\hline Companies which has a complete data in 2011-2015. & 12 \\
\hline Total samples & 12 \\
\hline
\end{tabular}

Table 2

Sample Selection Procedure for Non-Fraud Companies

\begin{tabular}{|l|l|}
\hline Sample criteria & $\begin{array}{l}\text { Companies that } \\
\text { meet the criteria }\end{array}$ \\
\hline $\begin{array}{l}\text { The population of non-financial companies where listing on } \\
\text { the BEI in 2011-2015 }\end{array}$ & 411 \\
\hline $\begin{array}{l}\text { Have a period of time and sector as fraud companies where } \\
\text { violating article no. VIII.G.7 sanctioned by the OJK in 2011- } \\
2015\end{array}$ & 88 \\
\hline Companies which has a complete data in 2011-2015. & 32 \\
\hline Total samples & 32 \\
\hline
\end{tabular}

\subsection{Descriptive Testing}

The following explanation is the result of data processing descriptive statistical analysis to obtain a general description associated with independent, moderating and dependent variables using SPSS 22.0 on the Table 3 below. 
Table 3

Descriptive Statistics Results

\begin{tabular}{|l|l|l|l|l|l|}
\hline Variable & $\mathrm{N}$ & Minimum & Maximum & Mean & $\begin{array}{l}\text { Standard } \\
\text { Deviation }\end{array}$ \\
\hline Financial Targets & 44 & -.12 & .44 & .0921 & .12124 \\
\hline $\begin{array}{l}\text { Innefective } \\
\text { Monitoring }\end{array}$ & 44 & .14 & .50 & .03510 & .09081 \\
\hline Change in Auditor & 44 & .00 & 1.00 & .6410 & .48597 \\
\hline Change in Direction & 44 & .00 & 1.00 & .4103 & .49831 \\
\hline $\begin{array}{l}\text { Board of } \\
\text { Commissioners }\end{array}$ & 44 & 2.00 & 8.00 & 4.0513 & 1.45002 \\
\hline $\begin{array}{l}\text { Independent } \\
\text { Commissioners }\end{array}$ & 44 & 1.00 & 3.00 & 1.3846 & .54364 \\
\hline $\begin{array}{l}\text { Institutional } \\
\text { Ownership }\end{array}$ & 44 & .25 & .91 & .5685 & .14730 \\
\hline Accounting Fraud & 44 & .00 & 1.00 & .3573 & .46757 \\
\hline
\end{tabular}

\subsection{Hypothesis Testing}

The result of hypothesis testing using binary logistic regression presented in Table 4.

Table 4

Hypothesis Test Results

\begin{tabular}{|l|l|l|}
\hline Variable & Significance & Description \\
\hline $\mathrm{X} 1 \longrightarrow \mathrm{Y}$ & 0.113 & Hypothesis 1 Rejected \\
\hline $\mathrm{X} 2 \longrightarrow \mathrm{Y}$ & 0.226 & Hypothesis 2 Rejected \\
\hline $\mathrm{X} 3 \longrightarrow \mathrm{Y}$ & 0.121 & Hypothesis 3 Rejected \\
\hline $\mathrm{X} 4 \longrightarrow \mathrm{Y}$ & $0.011^{*}$ & Hypothesis 4 Accepted \\
\hline $\mathrm{X} 1^{*} \mathrm{Z} 1 \longrightarrow \mathrm{Y}$ & 0.567 & Hypothesis 5a Rejected \\
\hline $\mathrm{X} 2^{*} \mathrm{Z} 1 \longrightarrow \mathrm{Y}$ & 0.175 & Hypothesis 5b Rejected \\
\hline $\mathrm{X} 3^{*} \mathrm{Z} 1 \longrightarrow \mathrm{Y}$ & 0.831 & Hypothesis 5c Rejected \\
\hline $\mathrm{X} 4^{*} \mathrm{Z} 1 \longrightarrow \mathrm{Y}$ & $0.028^{*}$ & Hypothesis 5d Accepted \\
\hline $\mathrm{X} 1^{*} \mathrm{Z} 2 \longrightarrow \mathrm{Y}$ & 0.253 & Hypothesis 6a Rejected \\
\hline $\mathrm{X} 2^{*} \mathrm{Z} 2 \longrightarrow \mathrm{Y}$ & 0.427 & Hypothesis 6b Rejected \\
\hline $\mathrm{X} 3^{*} \mathrm{Z} 2 \longrightarrow \mathrm{Y}$ & 0.550 & Hypothesis 6c Rejected \\
\hline $\mathrm{X} 4^{*} \mathrm{Z} 2 \longrightarrow \mathrm{Y}$ & $0.023^{*}$ & Hypothesis 6d Accepted \\
\hline $\mathrm{X} 1^{*} \mathrm{Z} 3 \longrightarrow \mathrm{Y}$ & 0.645 & Hypothesis 7a Rejected \\
\hline $\mathrm{X} 2^{*} \mathrm{Z} 3 \longrightarrow \mathrm{Y}$ & 0.816 & Hypothesis 7b Rejected \\
\hline $\mathrm{X} 3^{*} \mathrm{Z} 3 \longrightarrow \mathrm{Y}$ & 0.240 & Hypothesis 7c Rejected \\
\hline $\mathrm{X} 4^{*} \mathrm{Z} 3 \longrightarrow \mathrm{Y}$ & $0.015^{*}$ & Hypothesis 7d Accepted \\
\hline
\end{tabular}

*) Level of Significance: $0.05(5 \%)$

In Table 4, it shows that $\mathrm{H} 1$ test results obtained significance value of $0.113(>0.05)$ thus $\mathrm{H} 1$ rejected. This result in line with the research results of (Puspatrisnanti, 2014; Skousen et al., 2009; Sukirman and Sari, 2013) show that ROA has no effect on accounting fraud. H2 test results obtained significance value of $0.226(>0.05)$ thus $\mathrm{H} 2$ rejected. This results are similar to the research result of (Rahmanti and Daljono, 2013; Ratmono et al., 2014; Skousen et al., 2009) showed that ineffective monitoring has no effect on accounting fraud. Furthermore, testing H3 obtained significance value of 0.121 ( $>0.05)$ thus H3 rejected. This result in line with the research results of (Fimanaya and Syafruddin, 2014; Ratmono et al., 2014) where rationalization has no effect on accounting fraud. Then, H4 test obtained significance value $0.011(<0.05)$ thus H4 accepted. Change in Direction is causing stress period, adaptation and adjustment which open opportunities for fraud.

The H5a test with significance value of $0.567(>0.05)$, H5b with significance value of $0.175(>0.05)$, $\mathrm{H} 5 \mathrm{c}$ with significance value of $0.831(>0.05)$ and $\mathrm{H} 5 \mathrm{~d}$ with significance value $0.028(<0.05)$. Thus H5a, $\mathrm{H} 5 \mathrm{~b}$, and $\mathrm{H} 5 \mathrm{c}$ are rejected but $\mathrm{H} 5 \mathrm{~d}$ is accepted. Board of commissioners are able to moderate, in this case 
weakening the relationship ofchange in direction towards accounting fraud because corporate governance mechanisms can be used by the company to align ownership and management interests.

The result of H6a test with significance value of $0.253(>0.05)$, H6b with significance value of 0.427 (> 0.05), H6c with significance value of $0.550(>0.05)$ and H6d with significance value $0.023(<0.05)$, then H6a, H6b, H6c hypotheses are rejected while H6d accepted. Independent commissioners are able to moderate, in this case weakening the relationship of change in direction towards accounting fraud because independent commissioners originated from outside the company, so it is more focused and not easily influenced by anyone in the monitoring, controlling and managing. So, it is used to weaken the accounting fraud.

Furthermore, H7a test results with significance value of $0.645(>0.05)$, H7b with a significance value of $0.816(>0.05)$, H7c with a significance value of 0.240 and $\mathrm{H7d}$ with a significance value of 0.015 $(<0.05)$. Those test results show that H7a, H7b, H7c are rejected, but for H7d is acceptable. Institution ownership is able to moderate, in this case weakening the relationship of change in direction towards accounting fraud because corporate governance mechanisms focused on the owners of these companies will certainly prevent accounting fraud.

Based on the test, $\mathrm{H} 1, \mathrm{H} 5 \mathrm{a}, \mathrm{H} 6 \mathrm{a}$, and $\mathrm{H} 7 \mathrm{a}$ were rejected, test results $\mathrm{H} 2, \mathrm{H} 5 \mathrm{~b}, \mathrm{H} 6 \mathrm{~b}$, and $\mathrm{H} 7 \mathrm{~b}$ were rejected. For test results H3, H5c, H6c, and H7c rejected. For research results H4, H5d, H6d and H7d accepted.

\section{Research Limitations and Direction for Further Research 5.1 Research Limitations}

Limitations in this study is that the number of samples is relatively small, and due only conducted in manufacturing-companies only and only include 4 risk factors towards fraud and the only moderating variables is corporate governance.

\subsection{Direction for Further Research}

Based on the limitations of the research, it is necessary to do further development and improvement for the better subsequent studies. Some recommendations for further research are: (1) expanding the observation period for the larger amount of sample, (2) expanding the sample can be done by adding some other sectors or also including all companies listed in BEI, (3) furthermore, add other variables or predictors that may affect accounting fraud.

\section{References}

Albrecht, W. S., \& Albrecht, C. C. (2002). Root out financial deception. Journal of Accountancy, 193(4), 30.

Andayani, T. D. (2010). Pengaruh Karakteristik Dewan Komisaris Independen terhadap Manajemen Laba (Studi Pada Perusahaan Manufaktur yang Terdaftar di Bursa Efek Indonesia). Universitas Diponegoro.

Ansar, M. (2012). Analisis Faktor-Faktor Yang Mempengaruhi Kecurangan Pelaporan Keuangan Pada Perusahaan Publik Di Indonesia. Universitas Diponegoro. Semarang.

Antonia, E. (2008). Analisis Pengaruh Reputasi Auditor, Proporsi Dewan Komisaris Independen, Leverage, Kepemilikan Manajerial dan Proporsi Komite Audit Independen terhadap Manajemen Laba (Studi pada Perusahaan Manufaktur di Bursa Efek Indonesia Periode 2004-2006). program Pascasarjana Universitas Diponegoro.

Beiner, S., Drobetz, W., Schmid, F., \& Zimmermann, H. (2004). Is board size an independent corporate governance mechanism? Kyklos, 57(3), 327-356.

Brennan, N., \& Kelly, J. (2007). A study of whistleblowing among trainee auditors. The British Accounting Review, 39(1), 61-87.

Chen, K. Y., \& Elder, R. J. (2007). Fraud risk factors and the likelihood of fraudulent financial reporting: Evidence from statement on Auditing Standards No. 43 in Taiwan. Syracuse University Whitman School of Management Syracuse.

Cornett, M. M., Marcus, A. J., Saunders, A., \& Tehranian, H. (2007). The impact of institutional ownership on corporate operating performance. Journal of Banking $\mathcal{E}$ Finance, 31(6), 1771-1794.

Dechow, P. M., Sloan, R. G., \& Sweeney, A. P. (1996). Causes and consequences of earnings manipulation: An analysis of firms subject to enforcement actions by the SEC. Contemporary Accounting Research, 
13(1), 1-36.

Dunn, P. (2004). The impact of insider power on fraudulent financial reporting. Journal of Management, 30(3), 397-412.

Fimanaya, F., \& Syafruddin, M. (2014). Analisis Faktor-Faktor Yang Mempengaruhi Kecurangan Laporan Keuangan (Studi Empiris pada Perusahaan Non Keuangan Yang Terdaftar di Bursa Efek Indonesia Tahun 2008-2011). Diponegoro Journal of Accounting, 3(3), 1-11.

Ghozali, I. (2006). Applications Multivariate Analysis with SPSS Program. Semarang: Publisher Agency Diponegoro University.

Governance, K. N. K. C. (2004). Pedoman Good Corporate Governance Perbankan Indonesia. Bank Indonesia.

Jensen, M. C., \& Meckling, W. H. (1976). Theory of the firm: Managerial behavior, agency costs and ownership structure. Journal of Financial Economics, 3(4), 305-360.

Kasmir. (2013). Analisis Laporan Keuangan. In Rajawali Pers (Edisi 1, p. 202). Jakarta: Rajawali Pers.

Lim, S., Matolcsy, Z., \& Chow, D. (2007). The association between board composition and different types of voluntary disclosure. European Accounting Review, 16(3), 555-583.

Loebbecke, J. K., Eining, M. M., \& Willingham, J. J. (1989). Auditors experience with material irregularities-frequency, nature, and detectability. Auditing-A Journal of Practice $\mathcal{E}$ Theory, 9(1), 1-28.

Lou, Y., \& Wang, M. (2009). Fraud Risk Factor Of The Fraud Triangle Assessing The Likelihood Of Fraudulent Financial Reporting. Journal of Business \& Economics Research, 7(2), 61-78.

Marrakchi Chtourou, S., Bedard, J., \& Courteau, L. (2001). Corporate governance and earnings management.

Puspatrisnanti, T. (2014). Analisis Hubungan Manajemen Laba Dan Fraud Dalam Laporan Keuangan. Proceeding SNA, 16.

Rahmanti, M. M., \& Daljono, D. (2013). Pendeteksian Kecurangan Laporan Keuangan Melalui Faktor Risiko Tekanan dan Peluang (Studi Kasus pada Perusahaan yang Mendapat Sanksi dari Bapepam Periode 2002-2006). Fakultas Ekonomika dan Bisnis.

Ratmono, D., Avrie, D. Y., \& Purwanto, A. (2014). Dapatkah Teori Fraud Triangle Menjelaskan Kecurangan dalam Laporan Keuangan? Simposium Nasional Akuntansi, (17).

Sihombing, K. S., \& Rahardjo, S. N. (2014). Analisis Fraud Diamond dalam Mendeteksi Financial Statement Fraud: Studi Empiris pada Perusahaan Manufaktur yang Terdaftar di Bursa Efek Indonesia (BEI) Tahun 2010-2012. Fakultas Ekonomika dan Bisnis.

Skousen, C. J., Smith, K. R., \& Wright, C. J. (2009). Detecting And Predicting Financial Statement Fraud: The Effectiveness Of The Fraud Triangle And SAS NO . 99. Advances in Financial Economics, 13(99), 53-81. https:// doi.org/10.1108/S1569-3732(2009)0000013005

Stice, J. D. (1991). Using financial and market information to identify pre-engagement factors associated with lawsuits against auditors. Accounting Review, 516-533.

Sukirman, S., \& Sari, M. P. (2013). Model Deteksi Kecurangan Berbasis Fraud Triangle. JURNAL AKUNTANSI DAN AUDITING, 9(2), 199-225.

Syakhroza, A. (2005). Corporate Governance, Sejarah, \& Perkembangan Teori. Jakarta: Universitas Indonesia.

Tangjitprom, N. (2013). The role of corporate governance in reducing the negative effect of earnings management.

Tuanakotta, T. M. (2007). Akuntansi Forensik dan Audit Investigatif. Jakarta: Fakultas Ekonomi Universitas Indonesia.

Ujiyantho, M. A., \& Pramuka, B. A. (2007). Mekanisme Corporate Governance, Manajemen Laba dan Kinerja Keuangan. Simposium Nasional Akuntansi X, 26-28.

Widyastuti, T. (2009). Pengaruh struktur kepemilikan dan kinerja keuangan terhadap manajemen laba: Studi pada perusahaan manufaktur di BEJ. MAKSI, 9.

Wolfe, D. T., \& Hermanson, D. R. (2004). The fraud diamond: Considering the four elements of fraud. The CPA Journal, 74(12), 38. 